\title{
PENERAPAN METODE PICTURE AND PICTURE UNTUK MENINGKATKAN MINAT BELAJAR IPS SISWA KELAS I SD NEGERI 106162 MEDAN ESTATE
}

\author{
Syarifah Hasibuan ${ }^{1}$
}

Surel: syarifahhasibuan@gmai.com

\begin{abstract}
This research was conducted using interactive qualitative methods and classroom action research approaches. Each cycle includes planning, implementation, observation and reflection. The subject of this class action research is the first-semester students of grade I 106162 Medan Estate. Based on data analysis, it can be concluded that in cycle 1 student learning completeness in this material the average value is only 66.50 while in cycle 2 by applying learning strategies with picture and picture method increases reaching an average score of 90.00 Student responses also increase, Data from observations on teacher activity from $59.72 \%$ in cycle 1 , increased in cycle 2 to $93.06 \%$.
\end{abstract}

\section{Keywords: Interest, Method, Picture and Picture}

\begin{abstract}
ABSTRAK
Penelitian ini dilaksanakan dengan menggunakan metode kualitatif interaktif dan pendekatan penelitian tindakan kelas. Setiap siklus meliputi perencanaan, pelaksanaan, observasi dan refleksi. Adapun subjek penelitian tindakan kelas ini adalah siswa kelas I semester genap SD Negeri 106162 Medan Estate. Berdasarkan analisis data dapat disimpulkan bahwa pada siklus 1 ketuntasan belajar siswa pada materi ini nilai rata-rata hanya 66,50 sedangkan pada siklus 2 dengan menerapkan strategi pembelajaran dengan metode picture and picture meningkat mencapai nilai rata-rata 90,00 Respon siswa juga meningkat, data hasil observasi terhadap aktivitas guru dari 59,72\% pada siklus 1, meningkat pada siklus 2 menjadi 93,06\%.
\end{abstract}

Kata Kunci: Minat, Metode, Picture and Picture

\section{PENDAHULUAN}

Dalam sekolah keberadaan guru sangatlah vital. Hal ini disebabkan karena bila dalam sekolah tanpa ada guru maka proses pendidikan tidak akan dapat berlangsung atau terlaksana. Program kelas tidak akan berarti bilamana tidak duwujudkan dengan adanya kegiatan. Untuk itu peranan guru sangat menentukan karena kedudukannya sebagai pengelola pendidikan diantara siwa-siswa dalam kelas. Sesuai dengan eksistensinya di sekolah, tugas utama seorang guru adalah mengajar sehingga setiap akan mengajar seseorang guru harus mempersiapkan suatu cara bagaimana agar yang diajarkan kepada siswa itu dapat 
diterima serta dapat dipahami dengan mudah. Selanjutnya dalam proses belajar mengajar peranan guru dalam memilih metode mana yang akan digunakan sangatlah penting. Hal ini disebabkan karena tugas utama guru adalah menyampaikan bahan pelajaran kepada siswa dengan harapan siswa dapat menerima dan memahamI aahanpelajaran dengan mudah.

Keberhasilan kegiatan belajar siswa di sekolah dipengaruhi oleh banyak faktor. Faktor tersebut dapat bersifat eksternal maupun internal, dan dapat menjadi penghambat atau penunjang proses belajar mengajar. Basuki Wibawa (Media Pengajaran, 2001 : 2) mengemukakan bahwa faktor-faktor yang dianggap turut menghambat proses belajar siswa di kelas mungkin berasal dari verbalisme, kekacauan makna, kegemaran berangan-angan atau persepsi yang tidak tepat. Namun kadang baik guru maupun siswa sering mengabaikannya.

Mengingat bahwa metode adalah cara yang dalam fungsinya merupakan suatu alat untuk mencapai tujuan, maka makin baik metode itu makin efektif pula pencapaian tujuan. Sehingga dapat dikatakan bahwa apabila guru dalam memilih metode mengajar tepat dan dilaksanakan sesuai dengan prosedur, diharapkan siswa dapat menerima dan memahami dengan baik apa yang diajarkan oleh guru.

Proses pembelajaran selama ini guru menerapkan sesuai RPP dengan langkah-langkah sebagai berikut : Kegiatan awal, kegiatan inti dan kegiatan akhir, metode dan strategi pembelajaran serta penilaian; Pada saat proses pembelajaran di kelas Ia dengan Mata Pelajaran IPS tentang mendeskripsikan Lingkungan rumah memakai metode ceramah, media tulisan guru di papan tulis dengan materi menceritakan kegiatan sehari-hari sebelum berangkat ke sekolah. Pada kegiatan inti : guru menjelaskan materi siswa mendengarkan. Guru mengadakan tanya jawab, sebagian siswa belum ada yang bertanya. Pada kegiatan akhir : guru mengadakan penilaian untuk mengetahui kemampuan siswa dalam belajar dengan hasil sebagai berikut : Nilai tertinggi : 70; Nilai terendah: 40 dan Rata - rata nilai: 50 Ternyata pembelajaran di kelas Ia mata pelajaran IPS kurang memuaskan hasilnya. Melihat realita di atas bahwa proses pembelajaran selama ini yang berlangsung di kelas belum memenuhi harapan guru, siswa dan sekolah. Hal ini karena guru dalam menyampaikan materi hanya menoton saja, sehingga membuat siswa bosan. Selain itu guru dalam proses pembelajaran hanya memakai metode ceramah sehingga membuat siswa pasif, mengantuk atau bermain sendiri. Di samping itu guru dalam menyampaikan materi tanpa alat peraga ataupun tidak memakai media pembelajaran yang sesuai sehingga membuat siswa tidak paham akan materi yang diajarkan.

Jadi proses pembelajaran selama ini banyak kekurangan - 
kekurangannya. Seperti diuraikan di atas tentang pemakaian metode yang monoton, media pembelajaran yang tidak sesuai maupun penyampaian materi yang tidak menarik siswa. Setelah menelaah proses pembelajaran yang sudah berlangsung dan sudah dilaksanakan dan diuraikan di atas maka permasalahan terletak pada guru sebagai penyaji materi. Permasalahan-permasalah itu sebagaI berikut : Tujuan pembelajaran belum tercapai karena guru kurang menguasai materi; Alat atau media yang digunakan guru kurang sesuai atau kurang tepat dan Siswa pasif karena guru dalam penyampaian materi kurang memakai metode yang bervariasi dan keaktifan anak kurang karena kegiatan hanya berpusat pada guru.

Maka melihat hasil proses pembelajaran tersebut kurang memuaskan, maka peniliti nantinya akan melakukan penelitian mengambil mata pelajaran IPS tentang mendeskripsikan Lingkungan rumah di kelas Ia, dengan mengadakan perbaikan perbaikan. Sampai nilai siswa kelas Ia mencapai yang diharapkan selama ini.

Dengan cara menelaah : Nilai belajar siswa pada mata pelajaran IPS, Daftar hadir siswa (absensi), catatan keaktifan siswa, dsb. Melihat realita di atas maka guru harus dapat melaksanakan perbaikan sistem pembelajaran, selama ini pembelajaran yang dilaksanakan tanpa menggunakan alat peraga kurang menarik perhatian siswa, sehingga menyebabkan rendahnya prestasI belajar siswa. Selain itu dari berbagai sumber dijelaskan bahwa cara pembelajaran dengan menggunakan Metode Picture and Picture dapat meningkatkan minat belajar siswa sehingga diharapkan prestasi belajar dapat memuaskan. Untuk mengetahuI benar tidaknya penggunaan Metode Picture and Picture dapat meningkatkan prestasi IPS maka perlu diadakan penelitian.

\section{METODE PENELITIAN}

Tempat yang peneliti jadikan pelaksanaan penelitian tindakan kelas ini adalah di SD Negeri 106162 Medan Estate Tempat penelitian berlokasi di SD Negeri 106162 Medan Estate Kabupaten Deli Serdang, dimana tempat ini sekaligus tempat peneliti melaksanakan tugas mengajar. Alasan peneliti memilih tempat tersebut adalah : 1) Lokasinya dekat dengan rumah peneliti sehingga mudah dijangkau, 2) Peneliti saat ini menjadi salah satu guru yang mengajar di sekolah tersebut sehingga memudahkan peneliti untuk melaksanakan penelitian tindakan kelas ini. Penelitian tindakan kelas ini dilaksanakan dalam waktu yang cukup singkat yaitu dalam waktu Selama 3 bulan yaitu bulan Februari s/d April 2018.

Penelitian ini adalah seluruh siswa kelas Ia SD Negeri 106162 Medan Estate Kabupaten Deli Serdang Semester genap Tahun Pelajaran 2017/2018 sebanyak 27 
siswa, Pengambilan subyek penelitian ini didasarkan pada kondisi kelas yang diampu peneliti sekaligus mampu mewakili siswa kelas I secara keseluruhan.

Pada penelitian ini, pengumpulan data dilakukan dengan menggunakan teknik sebagai berikut:

a. Test yang dilaksanakan melalui:

1. Pre Test untuk pengumpulan data awal berkenaan dengan kemampuan siswa terhadap materi.

2. Post Test setelah siswa mengikuti suatu proses perlakuan yang dilakukan peneliti, guru memberikan soal-soal post test sehingga didapatkan hasil yang akurat dan dapat menggambarkan secara jelas kemampuan awal dan akhir siswa dalam menguasai materi tersebut.

b. Observasi, dengan menggunakan lembar observasi untuk mengumpulkan data tentang partisipasi dan aktivitas siswa dalam PBM dan implementasi pembelajaran dengan Metode Picture and Picture

c. Diskusi antara guru, teman sejawat dan Observer, dengan menggunakan lembar pengamatan untuk refleksi hasil siklus PTK.
Alat pengumpulan data dalam penelitian ini adalah:

a. Tes, digunakan untuk mendapatkan data tentang pemahaman siswa berupa tes tertulis menggunakan butir soal/instrumen soal yang telah dirancang oleh peneliti sesuai dengan tujuan yang telah tertuang dalam kisikisi soal untuk mengukur pemahaman siswa sebagai hasil belajar siswa.

b. Observasi, untuk mengumpulkan data tentang partisipasi dan aktivitas siswa dalam PBM dan implementasi pembelajaran dengan metode picture and picture.

c. Diskusi antara guru, teman sejawat dan observer, untuk refleksi hasil siklus PTK.

Data yang diperoleh pada setiap kegiatan observasi dari setiap siklus dianalisis secara deskriftif dengan menggunakan teknik persentase untuk melihat kecenderungan yang terjadi dalam proses pembelajaran. Kegiatan analisis meliputi:

1. Tingkat aktivitas belajar siswa dalam proses pembelajaran, dengan 
kategori tinggi, sedang dan rendah.

2. Tingkat pemahaman siswa berupa nilai dari hasil tes.

3. Tingkat keberhasilan strategi pembelajaran Metode Picture and Picture dengan kategori berhasil, kurang berhasil dan tidak berhasil.

Analisis data dilakukan dalam suatu proses yang berarti bahwa pelaksanaannya sudah mulai dilakukan sejak pengumpulan data dan dikerjakan secara intensif sesudah meninggalkan lapangan. (Lexi J. Moleong, 1999: 104). Sedangkan teknik yang digunakan adalah teknik analisis data kualitatif yang dikembangkan oleh Miles dan Huberman (1992: 18-19) yang terdiri dari tiga tahap: (1) mereduksi data; (2) menyajikan data; (3) verifikasi dan menarik kesimpulan.

\section{HASIL DAN PEMBAHASAN}

Penelitian ini dimulai dengan pemberian tes awal yang berfungsi mengukur kemampuan dasar yang dimiliki siswa dan memastikan perlu tidaknya tindakan diberikan pada materi Mendeskripsikan lingkungana rumah. Berdasarkan hasil tes awal, diperoleh data sebanyak 24 orang siswa telah mampu mendeskripsikan gambar dan 4 orang belum mampu.

Dari dua siklus tindakan yang diberikan, dapat dinyatakan bahwa ada peningkatan kemampuan siswa mendeskripsikan gambar-gambar.

Pada aktivitas siswa terjadi peningkatan, pada siklus 1 hanya
$64,58 \%$, meningkat menjadi 89,58 pada siklus II.

Pada aktivitas guru juga meningkat, dari $61,11 \%$ pada siklus 1 menjadi 90,27\% pada siklus II.

Pada kemampuan siswa pada tes awal hanya 7 siswa yang mampu mendeskripsikan. Setelah dilakukan tindakan meningkat menjadi 15 siswa pada siklus 1 , kemudian pada siklus 2 meningkat mencapai 23 siswa. Sesuai dengan indikator kinerja maka penelitian ini telah mencapai nilai aman dan penelitian tidak perlu dilanjutkan lagi.

Perlu diketahui, sampai akhir siklus 2 masih ada nilai 4 orang siswa $(14,18 \%)$ belum mampu, sehingga diperlukan diberikan perlakuan khusus sehingga nilai siswa tersebut dapat tuntas. Dengan demikian, dari 27 orang siswa, 23 orang siswa $(85,82 \%)$ dinyatakan telah mampu mendeskripsikan gambar-gambar.

Peningkatan ini jika dilihat dari tindakan yang dilakukan telah sesuai dengan apa yang diharapkan. Selain meningkatkan aktivitas siswa dalam pembelajaran, perasaan senang juga muncul dari siswa. Dan pemahaman siswa menjadi meningkat. Peningkatan ini diyakini sebagai pengaruh penerapan pembelajaran Metode Picture and Picture yang dapat meningkatkan kemampuan siswa mendeskripsikan gambar dan meningkatkan daya nalar siswa.

\section{SIMPULAN}




\begin{abstract}
Berdasarkan hasil analisis data dan pembahasan belajar mendeskripsikan lingkungan rumah dengan metode picture and picture pada pelajaran IPS siswa kelas II SDN 106162 Medan Estate dapat disimpulkan sebagai berikut:
\end{abstract}

1. Pembelajaran belajar mendeskripsikan lingkungan rumah dengan menggunakan metode picture and picture dilaksanakan dengan urutan:

1. Guru menyampaikan tujuan pembelajaran atau kompetensi yang ingin dicapai.

2. Memberikan materi pengantar sebelum kegiatan.

3. Guru menyediakan gambargambar yang akan digunakan (berkaitan dengan materi).

4. Guru menunjuk siswa secara bergilir untuk mengurutkan atau memasangkan gambargambar yang ada.

5. Guru memberikan pertanyaan mengenai alasan siswa dalam menentukan urutan gambar.

6. Dari alasan tersebut guru akan mengembangkan materi dan menanamkan Konsep materi yang sesuai dengan kompetensi yang ingin dicapai.

Pada akhir pembelajaran, 30 menit terakhir peneliti melakukan evaluasi dengan meminta siswa Mendeskripsikan gambar-gambar yang telah disusun oleh siswa secara individual.
2. Pembelajaran mendeskripsikan Gambar-gambar pelajaran IPS dengan menggunakan metode picture and picture meningkatkan aktivitas pembelajaran, mempertinggi interaksi antar siswa dan guru, serta meningkatkan pemahaman siswa terhadap materi sehingga kemampuan mendeskripsikan siswa meningkat.

3. Sebagai dorongan seorang guru harus bisa memberi motivasi bagi anak yang masih kurang mampu atau kurang lancar dalam membaca untuk lebih giat berlatih dan untuk anak yang sudah lancar agar terus belajar untuk lebih giat lagi.

4. Dengan metode picture and picture yang disajikan guru menggunakan media gambargambar, akan lebih meningkatkan kemampuan siswa.

\section{DAFTAR RUJUKAN}

Badudu, J.S. 1996. Pintar Berbahasa Indonesia 1: Petunjuk Guru Sekolah Lanjutan Tingkat Pertama. Jakarta: Balai Pustaka.

Djaali. 2008. Psikologi Pendidikan. CV Pendoman Ilmu Jaya: Jakarta.

Djamarah, Syaiful Bahri. 2002. Guru dan Anak Didik. Jakarta : Rineka Cipta.

Djamarah, Syaiful Bahri. 2011. Guru dan Anak Didik. Jakarta : Rineka Cipta. 
Drs. Hamdani, M.A. 2010. Strategi belajar mengajar. Bandung :Pustaka Setia.

Fathurrahman, Pupuh. 2007. Strategi Pembelajaran. Bandung: Insan Media.

Istarani, 2011. 58 Model Pembelajaran Inovatif (Referensi Guru Dalam Menentukan Model Pembelajaran). Medan : Media Persada.

Khodijah, Nyayu. 2014. Psikologi Pendidikan. Jakarta: Rajawali Pers.

Slameto. 2003. Belajar dan Faktorfaktor yang Mempengaruhinya. Jakarta: Rineka Cipta.

Roestiyah NK. 2008. Strategi Belajar

Mengajar. Jakarta : Rineka Cipta.

Slameto. 2003. Belajar dan Faktor -faktor yang Mempengaruhinya. Jakarta: Rineka Cipta.

Suhana, Cucu. 2014. Konsep Strategi Pembelajaran (Edisi Revisi). Bandung: Refika Aditama.

Sumadi Suryabrata. 2003. Metode Penelitian. Jakarta: Rajawali.

Susanto, ahmad. 2013. Teori Belajar dan Pembelajaran di Sekolah Dasar. Jakarta:
Kencana prenada media group.

Walgito. 2010. Psikologi Pendidikan. CV Pendoman Ilmu Jaya: Jakarta.

Wina Sanjaya. 2008. Strategi Pembelajaran Beorientasi Standar Proses Pendidikan. Jakarta: Kencana. 